\title{
ЗМІНИ ПЕРОКСИДНОГО ОКИСНЕННЯ ЛІПІДІВ ТА АНТИОКСИДАНТНОГО ЗАХИСТУ У ВИСОКО- І НИЗЬКОСТІЙКИХ ДО ГОСТРОЇ ГІПОКСИЧНОЇ ГІПОКСІЇ ЩУРІВ РІЗНОÏ СТАТІ ПРИ ІММОБІЛІЗАЦІЙНОМУ СТРЕСІ
}

Вступ. Визначення механізмів ушкоджувального впливу стресу на серце в осіб з різною реактивністю може сприяти розробці індивідуальних методів корекції.

Мета дослідження - визначити вплив іммобілізаційного стресу на зміни показників пероксидного окиснення ліпідів та антиоксидантного захисту в щурів різної статі з високою і низькою стійкістю до гіпоксії (ВГ, НГ).

Методи дослідження. Стрес моделювали 4 рази шляхом одногодинної іммобілізації щурів спинкою донизу з інтервалом 24 год. У серці визначали концентрацію дієнових і трієнових кон'югатів, шифрфових основ, ТБК-активних продуктів, активність супероксиддисмутази та каталази, у крові - концентрацію церулоплазміну, пероксидазну активність.

Результати й обговорення. У контрольних ВГ самців, порівняно з НГ, виявлено нижчу активність процесів пероксидного окиснення ліпідів, вищі активність супероксиддисмутази, концентрацію церулоплазміну, пероксидазну активність крові; у ВГ самиць порівняно з НГ - більше дієнових і трієнових кон'югатів, шифроових основ, менше ТБК-активних продуктів, вищі активність супероксиддисмутази, концентрацію церулоплазміну, пероксидазну активність крові, нижчу активність каталази. Іммобілізація призвела до зростання всіх досліджуваних продуктів пероксидного окиснення ліпідів (у тварин усіх груп найінтенсивніше збільшилися ТБК-активні продукти). У самиць також значно зросли шиффрові основи. Це вказує на розвиток оксидативного стресу, який більш виражений був у самців порівняно із самицями. У самиць продукти пероксидного окиснення ліпідів швидше метаболізувалися. Одночасно активувалась антиоксидантна система захисту: найбільще в самиць підвищилась активність супероксиддисмутази (більше у низькостійких до гіпоксії особин) і каталази (більше у високостійких до гіпоксії), в самців - концентрація церулоплазміну (найбільше у низькостійких до гіпоксії). Пероксидазна активність крові знизилася у тварин усіх досліджуваних груп.

Висновок. Іммобілізація щурів призводить до оксидативного стресу в серці, але механізм його розвитку і механізми адаптації та компенсації залежать від стійкості до гіпоксії і статі тварин.

КЛЮЧОВІ СЛОВА: стрес; щури; резистентність до гіпоксії; пероксидне окиснення ліпідів; антиоксидантна система.

ВСТУП. Індивідуальна реакція на стрес може залежати від віку, статі, особливостей автономної регуляції, стану центральної нервової, ендокринної систем, вищої нервової діяльності тощо [1]. Стрес $є$ невід'ємним супутником нашого життя [2]. Він може призводити як до адаптації, так і до її зриву, розвитку різноманітних захворювань [3]. При надмірному стресі порушується робота внутрішніх органів, зокрема серцевосудинної системи [4]. Гіподинамія, брак часу для виконання роботи, безробіття призводять до розвитку дистресу. Визначення патогенетичних ланок, які б змогли розкрити механізми ушкоджу( Ю. М. Ординський, О. В. Денесіль, 2019. вального впливу стресу, в осіб з різною реактивністю сприятиме розробці індивідуальних методів корекції.

Мета дослідження - визначити вплив іммобілізаційного стресу на зміни показників пероксидного окиснення ліпідів та антиоксидантного захисту в щурів різної статі з високою і низькою стійкістю до гіпоксії (ВГ, НГ).

МЕТОДИ ДОСЛІДЖЕННЯ. Досліди виконано на 96 щурах лінії Вістар, високо- і низькостійких до гіпоксії, віком 5,5-6 місяців. Тварин поділено на групи - контрольні та дослідні (які зазнали іммобілізаційного стресу). В кожній з груп було 
по 12 самців і 12 самиць. Особин з різною стійкістю до гіпоксії виділяли із загальної когорти тварин за методикою В. Я. Березовського [5]. Стрес моделювали шляхом чотириразової одногодинної іммобілізації щурів спинкою донизу 3 інтервалом 24 год між окремими стресовими епізодами [6].

Усі експерименти проводили в першій половині дня в спеціально відведеному приміщенні при температурі $18-22{ }^{\circ} \mathrm{C}$, відносній вологості 40-60 \% і освітленості 250 лк. Досліди виконано з дотриманням норм Європейської конвенції про захист хребетних тварин, що використовуються для дослідних та інших наукових цілей (Страсбург, 1986), ухвали Першого національного конгресу з біоетики (Київ, 2001) і наказу МОЗ України від 23.09.2009 р. № 690.

Евтаназію щурів проводили шляхом тотального кровопускання із серця після попереднього тіопентал-натрієвого наркозу (60 мг·к ${ }^{-1}$ маси тіла тварини внутрішньочеревно). Для подальшого експериментального дослідження в гомогенаті серця визначали концентрацію дієнових (ДК) і трієнових кон'югатів (ТК), шифрфових основ (ШО) [7], ТБК-активних продуктів (ТБК-АП) [8], активність супероксиддисмутази (СОД) [9], каталази (КАТ) [10], у сироватці крові - концентрацію церулоплазміну (ЦП) [11], пероксидазну активність (ПАК) [12].

Статистичну обробку цисррових даних виконано за допомогою програмного забезпечення Excel (Microsoft, CШA) i STATISTICA 6.0 (Statsoft, США). Достовірність різниці значень між незалежними кількісними величинами визначали при нормальному розподілі за критерієм Стьюдента, в інших випадках - непараметричними методами.
РЕЗУЛЬТАТИ Й ОБГОВОРЕННЯ. У КОНтрольних ВГ самців, порівняно з НГ, виявлено нижчу активність процесів пероксидного окиснення ліпідів (ПОЛ), про що свідчили достовірно менші на $6,78 \%(p<0,001)$ показники ТБК-активних продуктів (табл. 1). При іммобілізаційному стресі у ВГ тварин відмічено значне збільшення первинних і проміжних продуктів ПОЛ: ДК - на 13,57 \% (p<0,001), ТК - на 11,35 \% $(p<0,001)$, ТБК-АП - у 4,7 раза $(p<0,001)$, ШО на 76,7\% $(p<0,001)$. У НГ щурів значення ДК зросли на 33,46 \% $(p<0,001)$, ТК - на 38,11 \% $(p<0,001)$, ТБК-АП -у 3,08 раза $(p<0,001)$, ШО на $64,48 \%(p<0,001)$. У ВГ тварин, порівняно 3 НГ, виявлено такі показники ПОЛ: нижчі - ДК (на 21,15\%, p<0,001) і ТК (на 29,10\%, p<0,001); вищі - ТБК-активних продуктів (на 30,06 \%, p <0,001) та ШО (на 10,8 \%, p<0,001). Отримані дані вказують на розвиток оксидативного стресу у ВГ і НГ щурів-самців. У НГ тварин спостерігали накопичення первинних і вторинних продуктів ПОЛ, нижчу концентрацію ШО, що можна пов'язати з меншим антиоксидантним захистом, знешкодженням кінцевих продуктів. У ВГ щурів відмічено більше накопичення проміжних і кінцевих продуктів ПОЛ, що може свідчити про високу потужність антиоксидантної системи.

У контрольних ВГ самиць, порівняно з НГ, були більша активність первинних, проміжних і кінцевих продуктів ПОЛ (ДК - на 14,38\%, p<0,001, TK - на 15,24 \%, p<0,001, ШО - на 31,12\%, $\mathrm{p}<0,001)$ та менша концентрація ТБК-АП (на $8,01 \%, p<0,001)$. Отримані дані можуть вказувати на інтенсивніший перебіг процесів ПОЛ у інтактних ВГ самиць, що може бути пов'язано 3 недостатнім антиоксидантним захистом.

Таблиця 1 - Зміни показників пероксидного окиснення ліпідів, викликані іммобілізаційним

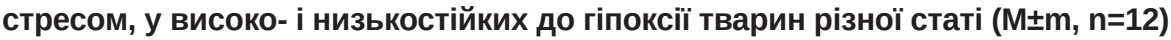

\begin{tabular}{|c|c|c|c|c|}
\hline \multirow[b]{2}{*}{ Група } & \multicolumn{4}{|c|}{ ППоказник } \\
\hline & $\begin{array}{c}\text { дієнові кон'югати, } \\
\text { ум. од. } \text { - }^{-1}\end{array}$ & $\begin{array}{c}\text { трієнові кон'югати, } \\
\text { ум. од. } \text { - }^{-1}\end{array}$ & $\begin{array}{c}\text { ТБК-активні продукти, } \\
\text { мкмоль/кг }\end{array}$ & $\begin{array}{c}\text { шифрфові основи, } \\
\text { ум. од. } \Gamma^{-1}\end{array}$ \\
\hline \multicolumn{5}{|c|}{ Високостійкі до гіпоксії самці } \\
\hline Контроль & $0,975 \pm 0,021$ & $0,994 \pm 0,013$ & $0,906 \pm 0,012$ & $1,413 \pm 0,100$ \\
\hline Стрес & $1,108 \pm 0,028 *$ & $1,107 \pm 0,028 *$ & $4,255 \pm 0,024^{*}$ & $2,496 \pm 0,063^{*}$ \\
\hline \multicolumn{5}{|c|}{ Низькостійкі до гіпоксії самці } \\
\hline Контроль & $1,005 \pm 0,010$ & $1,035 \pm 0,019$ & $0,967 \pm 0,006^{\star \star}$ & $1,354 \pm 0,055$ \\
\hline Стрес & $1,342 \pm 0,064^{\star, \star \star}$ & $1,429 \pm 0,017^{*, \star \star}$ & $2,976 \pm 0,061^{\star, \star \star}$ & 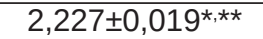 \\
\hline \multicolumn{5}{|c|}{ Високостійкі до гіпоксії самиці } \\
\hline Контроль & $0,952 \pm 0,024$ & $1,140 \pm 0,032^{\#}$ & $0,899 \pm 0,002$ & $1,100 \pm 0,016^{\#}$ \\
\hline Стрес & $1,027 \pm 0,023^{*, \#}$ & $1,091 \pm 0,015$ & $3,916 \pm 0,047^{*, \#}$ & $2,357 \pm 0,068 *$ \\
\hline \multicolumn{5}{|c|}{ Низькостійкі до гіпоксії самиці } \\
\hline Контроль & $0,861 \pm 0,006^{\star \star, \#}$ & $0,966 \pm 0,017^{* \star, \#}$ & $0,971 \pm 0,005^{\star \star}$ & $0,932 \pm 0,016^{\star \star, \#}$ \\
\hline Стрес & $1,110 \pm 0,054^{*, \#}$ & $1,141 \pm 0,047^{*, \#}$ & $3,900 \pm 0,008^{*, \#}$ & $2,264 \pm 0,062^{*}$ \\
\hline
\end{tabular}

Примітки. Тут і в таблиці 2:

1. * - показники достовірні порівняно з контролем; ** - показники достовірні порівняно з ВГ тваринами.

2. * - показники достовірні порівняно із самцями відповідної групи. 
При стресі у ВГ самиць відмічено значні зміни продуктів ПОЛ: показники ДК зросли на $7,83 \%(p<0,05)$, ТБК-АП -у 4,36 раза $(p<0,001)$, ШО - у 2,14 раза ( $<<0,001)$. У НГ самиць усі показники підвищилися: ДК - на 28,93\% $(p<0,001)$, ТК - на 18,16 \% ( $<<0,001)$, ТБК-АП у 4,02 раза ( $p<0,001)$, ШО - у 2,43 раза $(p<0,001)$. Різниці показників продуктів ПОЛ у ВГ і НГ тварин при стресі не відмічено. Отримані дані свідчать про те, що у ВГ та НГ самиць, як і в самців, виник оксидативний стрес, більше виражений у НГ.

У контрольних ВГ самців, порівняно з ВГ самицями, виявлено менші на 14,67\% (p<0,001) показники ТК і більші на 22,12 \% ( $<<0,002)$ значення ШО. У НГ самців, порівняно з НГ самицями, були вищими на 14,38 \% ( $<<0,001)$ показники ДК, на 31,12 \% (p<0,001) - ШО, нижчими на $6,63 \%(p<0,02)-$ ТК. Дані результати в самиць, порівняно із самцями, вказують на інтенсивніший перебіг у останніх ПОЛ, менш потужну роботу антиоксидантної системи, що спричинює знешкодження продуктів ПОЛ, оскільки утворюється більше ШО. При стресі відмічено інтенсивніший перебіг ПОЛ у самців. У ВГ самців, порівняно з ВГ самицями, показники ДК були вищими на 7,3 \% (p<0,05), ТБК-АП - на 7,95\% $(p<0,001)$; у НГ самців, порівняно з НГ самицями, значення ДК були більшими на 17,28 \% (p<0,01), ТК - на $20,11 \%(p<0,001)$, а ТБК-АП - меншими на $31,07 \%$ (р<0,001). Отже, в самців стрес спричинював інтенсивніший перебіг ПОЛ, що може бути пов'язано з вищою активацією симпатичного відділу автономної нервової системи, меншою потужністю або більшими витратами антиоксидантів, відсутністю протекторного впливу статевих гормонів.

При вивченні фрерментативної ланки антиоксидантного захисту (табл. 2) виявлено, що в контролі у серці ВГ самців, порівняно з НГ, була вищою на 37,33 \% ( $<<0,001)$ активність СОД. Отримані результати вказують на менший вміст продуктів ПОЛ у ВГ самців порівняно з НГ.

При стресі у ВГ самців активність антиоксидантів не змінилася, а в НГ активність СОД зросла на 89,42 \% (p<0,001), активність КАТ - на $17,43 \%$ ( $<<0,001)$. У НГ тварин активність КАТ виявилася меншою на 14,71 \% ( $<<0,001)$. Як свідчать отримані дані, нижча концентрація продуктів ПОЛ дійсно забезпечувалася вищою активністю антиоксидантного захисту організму у ВГ самців.

У контролі у ВГ самиць, порівняно з НГ, була вищою на 20,65 \% ( $<<0,001)$ активність СОД, нижчою в 3,07 раза ( $<<0,001)$ - активність КАТ. Отримані результати вказують на інтенсивніший перебіг ПОЛ і антиоксидантного захисту у ВГ самиць, більша ж активність КАТ у НГ тварин забезпечувала менше накопичення продуктів ПОЛ.

При стресі у ВГ самиць активність СОД зросла у 2,25 раза ( $p<0,001)$, КАТ - у 13,28 раза ( $<<0,001)$. У НГ самиць, відповідно, активність СОД збільшилася в 3,7 раза ( $p<0,001)$, КАТ - у 4,34 раза ( $<<0,001)$. Така потужна активація антиоксидантного захисту сприяла меншому накопиченню продуктів ПОЛ і, можливо, незначному ураженню кардіоміоцитів.

У контролі у ВГ самців, порівняно з НГ, була вищою на 15,90 \% (p<0,002) концентрація ЦП, на 18,13\% (р<0,001) - ПАК. Отримані результати пояснюють менший вміст продуктів ПОЛ у ВГ самців порівняно з НГ. При стресі у ВГ самців концентрація ЦП збільшилася в 16,68 раза ( $p<0,001)$, у НГ - у 20,18 раза $(p<0,001)$, ПАК знизилася у ВГ на 62,44 \% (p<0,001), у НГ - на $53,07 \%$ ( $<<0,001)$. Статистично достовірної різниці у досліджуваних показниках між ВГ і НГ тваринами не виявлено.

Таблиця 2 - Зміни показників антиоксидантної системи, викликані іммобілізаційним стресом, у гомогенаті серця та сироватці крові високо- і низькостійких до гіпоксії тварин

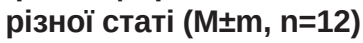

\begin{tabular}{|c|c|c|c|c|}
\hline \multirow[b]{2}{*}{ Група } & \multicolumn{4}{|c|}{ Показник } \\
\hline & $\begin{array}{c}\text { супероксиддисмутаза, } \\
\text { ум. од. } \text { мг }^{-1}\end{array}$ & $\begin{array}{l}\text { каталаза, } \\
\text { мкат/кг }\end{array}$ & $\begin{array}{c}\text { церулоплазмін, } \\
\text { мг/л }\end{array}$ & $\begin{array}{c}\text { пероксидазна активність } \\
\text { крові, мкмоль/(хв·л) }\end{array}$ \\
\hline \multicolumn{5}{|c|}{ Високостійкі до гіпоксії самці } \\
\hline Контроль & $0,98 \pm 0,02$ & $1,61 \pm 0,16$ & $2,35 \pm 0,09$ & $342,90 \pm 1,21$ \\
\hline Стрес & $1,02 \pm 0,16$ & $1,74 \pm 0,31$ & $39,18 \pm 2,79^{*}$ & $128,81 \pm 13,91^{*}$ \\
\hline \multicolumn{5}{|c|}{ Низькостійкі до гіпоксії самці } \\
\hline Контроль & $0,71 \pm 0,01^{\star \star}$ & $1,26 \pm 0,06$ & $2,03 \pm 0,05^{\star \star}$ & $322,48 \pm 3,38^{\star \star}$ \\
\hline Стрес & $1,35 \pm 0,02^{*}$ & $1,48 \pm 0,08^{*}$ & $40,91 \pm 0,64^{*}$ & $151,33 \pm 0,91^{*}$ \\
\hline \multicolumn{5}{|c|}{ Високостійкі до гіпоксії самиці } \\
\hline Контроль & $0,81 \pm 0,01^{\#}$ & $0,35 \pm 0,03^{\#}$ & $3,63 \pm 0,17^{\#}$ & $283,71 \pm 1,97^{\#}$ \\
\hline Стрес & $1,83 \pm 0,16^{\star, \#}$ & $4,71 \pm 0,48^{\star \#}$ & $14,15 \pm 0,14^{*, \#}$ & $111,86 \pm 6,21^{*}$ \\
\hline \multicolumn{5}{|c|}{ Низькостійкі до гіпоксії самиці } \\
\hline Контроль & $0,65 \pm 0,01^{\star \star, \#}$ & $1,09 \pm 0,01^{\star *, \#}$ & $2,43 \pm 0,06^{\star \star, \#}$ & $270,38 \pm 3,76^{\star \star, \#}$ \\
\hline Стрес & $2,39 \pm 0,30 *, \#$ & $4,73 \pm 0,22^{*, \#}$ & $13,68 \pm 0,20^{*, \#}$ & $159,24 \pm 5,44^{\star, \star \star}$ \\
\hline
\end{tabular}


У контролі у ВГ самиць, порівняно з НГ, була більшою на 33,13 \% $(p<0,001)$ концентрація ЦП,

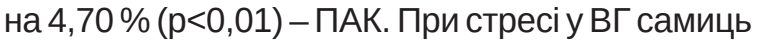
концентрація ЦП у ВГ тварин зросла у 3,90 раза $(p<0,001)$, у НГ - у 5,63 раза $(p<0,001)$. Пероксидазна активність знизилася у ВГ щурів на $60,57 \%(p<0,001)$, у НГ - на 41,11 \% ( $<<0,001)$ i була вищою у НГ тварин на 42,36 \% ( $<<0,001)$.

В інтактних самців, порівняно із самицями, спостерігали вищі активність супероксиддисмутази, каталази та пероксидазну активність, але нижчу концентрацію церулоплазміну. При стресі картина змінювалася: в серці самиць достовірно переважала активність супероксиддисмутази і каталази, а у крові самців - концентрація церулоплазміну; пероксидазна активність крові не відрізнялася між групами самців і самиць. Отримані дані вказують на те, що більша активація антиоксидантів у самиць забезпечує менше накопичення в серці продуктів пероксидації ліпідів.

Тільки в серці ВГ самців не відмічено компенсаторного зростання антиоксидантних ензимів, що, можливо, пов'язано з вмістом вуглекислого газу. 3 одного боку, вуглекислота захищає СОД від інактивації, а з іншого - утворюється вільний карбонатний радикал, здатний призвести до окисного ушкодження клітини. Карбонатний радикал стабільний і може легко дифундувати 3 місця утворення, призводячи до окисного ушкодження клітини, він має здатність до димеризації, що може слугувати одним із шляхів його детоксикації [13].

ВИСНОВКИ. 1. У серці інтактних високостійких до гіпоксії щурів-самців, порівняно з низько- стійкими тваринами такого ж віку, спостерігають меншу активність процесів пероксидного окиснення ліпідів (за рахунок ТБК-активних продуктів); у високостійких самиць - більшу за рахунок дієнових і трієнових кон'югатів та шифффових основ, у низькостійких - за рахунок ТБК-активних продуктів. У високостійких самців і самиць більша потужність антиоксидантної системи (активність супероксиддисмутази, пероксидазна активність, концентрація церулоплазміну).

2. Іммобілізаційний стрес призводить до розвитку оксидативного стресу в щурів: у високостійких самців - за рахунок ТБК-активних продуктів та шифффових основ, у низькостійких дієнових і трієнових кон'югатів; у високостійких самиць - ТБК-активних продуктів і шифрсрових основ, у низькостійких - дієнових і трієнових кон'югатів, ТБК-активних продуктів та шифффових основ. Інтенсивніший перебіг процесів ПОЛ при стресі спостерігають у самців порівняно із самицями.

3. При стресі в серці відмічено активацію антиоксидантної системи захисту, що було більш виражено в самиць порівняно із самцями. У високостійких до гіпоксії самців зростання активності супероксиддисмутази і каталази не відмічено. Концентрація церулоплазміну більше підвищувалася в самців, а пероксидазна активність крові знижувалася в усіх тварин.

Перспективи подальших досліджень. Для визначення механізмів кардіопротекторної дії буде проведено аналіз вегетативного забезпечення серцевого ритму та морфологічне дослідження серця і надниркових залоз.

\section{СПИСОК ЛІТЕРАТУРИ}

1. Crea F. Sex differences in mechanisms, presentation and management of ischaemic heart disease / F. Crea, I. Battipaglia, F. Andreotti // Atherosclerosis. 2015. - 241 (1). - P. 157-168.

2. Kötter T. Resource-oriented coaching for reduction of examination-related stress in medical students: an exploratory randomized controlled trial / T. Kötter, F. Niebuhr // Adv. Med. Educ. Pract. - 2016. - 7. P. 497-504.

3. Expressive flexibility in combat veterans with posttraumatic stress disorder and depression / R. Rodin, G. A. Bonanno, N. Rahman [et al.] // J. Affect. Disord. 2016. - 207. - P. 236-241.

4. Angina and mental stress-induced myocardial ischemia / P. Pimple, A. J. Shah, C. Rooks [et al.] // J. Psychosom. Res. - 2015. - 78 (5). - P. 433-437.
5. Березовский В. А. Гипоксия и индивидуальные особенности реактивности / В. А. Березовский. - К. : Наукова думка, 1978. - 216 с.

6. Кулинский В. И. Две адаптационные стратегии в неблагоприятных условиях: резистентная и толерантная. Роль гормонов и рецепторов / В. И. Кулинский, И. А. Ольховский // Успехи современной биологии. -1992. - 112. - С. 697-711.

7. Хышиктуев Б. С. Методы определения продуктов перекисного окисления липидов в конденсате выдыхаемого воздуха и их клиническое значение / Б. С. Хышиктуев, Н. А. Хышиктуева, В. Н. Иванов // Клинич. лаб. диагностика. - 1996. - № 3. - С. 13-15.

8. Доклінічні дослідження лікарських засобів : метод. рек. / за ред. О. В. Стесранова. - К. : Авіцена, 2001. -528 c. 
9. Чевари С. Роль супероксиддисмутазы в окислительных процессах клетки и метод определения ее в биологических материалах / С. Чевари, И. Чаба й. Секей // Лаб. дело. - 1985. - № 11. - С. 678-681.

10. Метод определения активности каталазы / М. А. Королюк, Л. И. Иванова, И. Г. Майорова, В. Е. Токарев // Лаб. дело. - 1988. - № 1. - С. 16-19.

11. Клінічна та лабораторна діагностика. Нормативні, директивні, правові документи : збірник : в 2-х ч. / головн. ред. В. М. Заболотько. - К. : МВЦ "Медінорорм", 2003. - 856 с.

12. Попов Т. Метод определения пероксидазной активности крови / Т. Попов, Л. Нейковская // Гигиена и санитария. - 1971. - № 10. - С. 89-93.

13. Морозова В. С. Функціонування антиоксидантної системи міокарду щурів за умов штучного гіпобіозу / В. С. Морозова // Вісн. проблем біології і медицини. - 2013. - 2 (103), вип. 3. - С. 86-90.

\section{REFERENCES}

1. Crea, F., Battipaglia, I., \& Andreotti, F. (2015). Sex differences in mechanisms, presentation and management of ischaemic heart disease. Atherosclerosis, 241 (1), 157-168.

2. Kötter, T., \& Niebuhr, F. (2016). Resource-oriented coaching for reduction of examination-related stress in medical students: an exploratory randomized controlled trial. Adv. Med. Educ. Pract., 7, 497-504.

3. Rodin, R., Bonanno, G.A., Rahman, N., Kouri, N.A., Bryant, R.A., Marmar, C.R., \& Brown, A.D. (2016). Expressive flexibility in combat veterans with posttraumatic stress disorder and depression. J. Affect. Disord., 207, 236-241.

4. Pimple, P., Shah, A.J., Rooks, C., Bremner, J.D., Nye, J., Ibeanu, I., Raggi P., \& Vaccarino, V. (2015). Angina and mental stress-induced myocardial ischemia. J. Psychosom. Res., 78 (5), 433-437.

5. Berezovskyy, V.A. (1978). Gipoksiya i individualnye osobennosti reaktivnosti [Hypoxia and individual particularities of reactivity]. Kyiv: Naukova dumka [in Russian].

6. Kulynskyy, V.I., \& Olkhovskyy, I.A. (1992). Dve adaptatsionnye strategii v neblagopriyatnykh usloviyakh: rezistentnaya i tolerantnaya. Rol gormonov i retseptorov [Two adaptation strategies in adverse conditions: resistant and tolerant. The role of hormones and receptors]. Uspekhi sovremennoy biologii - Advances of Modern Biology, 112, 697-711 [in Russian].

7. Khyshiktuev, B.S., Khyshiktueva, N.A., \& Ivanov, V.N. (1996). Metody opredeleniya produktov perekisnogo okisleniya lipidov $v$ kondensate vydykhayemogo vozdukha i ikh klinicheskoye znacheniye [Methods of determination of products of lipids peroxidation in exhaled air condensate and their clinical significance]. Klini- cheskaya laboratornaya diagnostika - Clinical Laboratory Diagnostics, 3, 13-15 [in Russian].

8. Stefanov, O.V. (Ed.). (2001). Doklinichni doslidzhennia likarskykh zasobiv: metodychni rekomendatsii [Preclinical research of medicinal products: methodical recommendations]. Kyiv: Avitsenna [in Ukrainian].

9. Chevary, S., Chaba, Y., \& Sokey, Y. (1985). Rol superoksiddysmutazy $v$ okislitelnykh protsessakh kletki i metod opredeleniya ee $v$ biologicheskikh materialakh [The role of superoxide dismutase in the oxidative processes of the cell and the method for its determination in biological materials]. Laboratornoye Delo - Laboratory Work, 11, 678-681 [in Russian].

10. Korolyuk, M.A., Ivanova. L.I., Mayorova, I.G., \& Tokarev, V.E. (1988). Metod opredeleniya aktivnosti katalazy [Method for determination of catalase activity]. Laboratornoye delo - Laboratory Work, 1, 16-19 [in Russian].

11. Zabolotko, V.M. (Ed). (2003). Klinichna ta laboratorna diahnostyka. Normatyvni, dyrektyvni, pravovi dokumenty: zbirnyk: $v 2 \mathrm{ch}$. [Clinical and laboratory diagnostic. Norm, directive, low documents: in 2 parts]. Kyiv: MEC "Medinform" [in Ukrainian].

12. Popov, T., \& Neykovska, L. (1971). Metod opredeleniya peroxidaznoy aktivnosti krovi [Method for determination of blood peroxides activity]. Gigiyena $i$ sanitariya - Hygiene and Sanitary, 10, 89-93 [in Russian].

13. Morozova, V.S. (2013). Funktsionuvannia antyoksydantnoi systemy miokardu shchuriv za umov shtuchnoho hipobiozu [Functioning of the antioxidant system of myocardium of rats under conditions of artificial gipobiosis]. Visnyk problem biolohii i medytsyny - Bulletin of Biological and Medical Problems, 2 (103), 3, 86-90 [in Ukrainian]. 


\section{ИЗМЕНЕНИЯ ПЕРЕКИСНОГО ОКИСЛЕНИЯ ЛИПИДОВ И АНТИОКСИДАНТНОЙ ЗАЩИТЫ У ВЫСОКО- И НИЗКОУСТОЙЧИВЫХ К ОСТРОЙ ГИПОКСИЧЕСКОЙ ГИПОКСИИ КРЫС РАЗНОГО ПОЛА ПРИ ИММОБИЛИЗАЦИОННОМ СТРЕССЕ}

\section{Резюме}

Вступление. Определение механизмов повреждающего воздействия стресса на сердце у особей с различной реактивностью может способствовать разработке индивидуальных методов коррекции.

Цель исследования - определить влияние иммобилизационного стресса на изменения показателей перекисного окисления липидов и антиоксидантной защиты у крыс разного пола с высокой и низкой устойчивостью к гипоксии (ВГ и НГ).

Методы исследования. Стресс моделировали 4 раза путем одночасовой иммобилизации крыс спинкой вниз с интервалом 24 ч. В сердце определяли концентрацию диеновых и триеновых конъюгатов, шифрфовых оснований, ТБК-активных продуктов, активность супероксиддисмутазы и каталазы, в крови - концентрацію церулоплазмина, пероксидазную активность.

Результаты и обсуждение. У контрольных ВГ самцов, по сравнению с НГ, выявлено более низкую активность процессов перекисного окисления липидов, более высокие активность супероксиддисмутазы, концентрацию церулоплазмина, пероксидазную активность крови; у ВГ самок по сравнению с НГ - больше диеновых и триеновых конъюгатов, шифроовых оснований, меньше ТБК-активных продуктов, более высокие активность супероксиддисмутазы, концентрацию церулоплазмина, пероксидазную активность крови, более низкую активность каталазы. Иммобилизация привела к росту всех исследуемых продуктов перекисного окисления липидов (у животных всех групп интенсивнее всего увеличились ТБК-активные продукты). У самок также значительно выросли шиффровые основания. Это указывает на развитие оксидативного стресса, который более выражен был у самцов по сравнению с самками. У самок продукты перекисного окисления липидов быстрее метаболизировались. Одновременно активизировалась антиоксидантная система защиты: больше всего у самок повысилась активность супероксиддисмутазы (больше у низкоустойчивых к гипоксии особей) и каталазы (больше у высокоустойчивых к гипоксии), у самцов - концентрация церулоплазмина (больше всего у низкоустойчивых к гипоксии). Пероксидазная активность крови снизилась у животных всех исследуемых групп.

Вывод. Иммобилизация крыс приводит к оксидативному стрессу в сердце, но механизмы его развития и механизмы адаптации и компенсации зависят от устойчивости к гипоксии и пола животных.

КЛЮЧЕВЫЕ СЛОВА: стресс; крысы; резистентность к гипоксии; перекисное окисление липидов; антиоксидантная система.

\section{CHANGES OF LIPID PEROXIDATION AND ANTIOXIDANT DEFENSE OF HIGH AND LOW-RESISTANCE TO ACUTE HYPOXIC HYPOXIA IN RATS OF DIFFERENT SEX IN IMMOBILIZATIONAL STRESS}

\section{Summary}

Introduction. Determining the mechanisms of damaging the influence of stress on the heart in persons with different reactivity can contribute to the development of individual methods of correction.

The aim of the study - to determine the effect of immobilization stress on changes in peroxide lipid oxidation and antioxidant defense in rats of different sex with high and low resistance to hypoxia (HR, LR).

Research Methods. Stress was modeled 4 times by an hour immobilization of rats on a back down with an interval of 24 hours. In the heart, the diene and triaene conjugates, schiff bases, TBA-active products, superoxide dismutase (SOD), catalase activity in heart and ceruloplasmine and activity of peroxides were determined.

Results and Discussion. In control HR males, in comparison with LR, lower activity of lipid peroxidation, higher activity of SOD, concentration of ceruloplasmine, blood peroxides were observed; in HR-females, in comparison with $L R$, more diene and triene conjugates, schiff bases, SOD, ceruloplasmine and activity of peroxides; less 
TBA-active products and lower catalase activity. Immobilization led to an increase in all investigated products of lipid peroxidation (in all groups of animals the TBA-active products increased the most intensively). The schiff bases also significantly increased in females. This indicates the development of oxidative stress, which is more pronounced in males than in females. In females, lipid peroxidation products metabolize faster, than in males. At the same time, the antioxidant defense system was activated: the superoxide dismutase activity (more in low resistance to hypoxia animals) and catalase activity (more in high resistance to hypoxia individuals) increased maximally in the females, and in males, the concentration of ceruloplasmin (most notably in low resistance to hypoxia animals). The peroxidase activity of blood decreased in all observed groups of animals.

Conclusions. Immobilization of rats leads to oxidative stress in the heart, but the mechanisms of their development, adaptation and compensation depend on resistance to hypoxia and sex of animals.

KEY WORDS: stress; rats; resistance to hypoxia; lipid peroxidation; antioxidant system.

Отримано 03.05.19

Адреса для листування: О. В. Денефріль, Тернопільський державний медичний університет імені І. Я. Горбачевського, майдан волі, 1, Тернопіль, 46001, Україна, e-mail: denefil@tdmu.edu.uа. 